\title{
A VISITA DO IMPERADOR PEDRO II AO NORTE DA PROVÍNCIA DO RIO DE JANEIRO: DISPUTAS POLÍTICAS NO $4^{\circ}$ DISTRITO ELEITORAL (1844/1848)
}

\author{
THE VISIT OF EMPEROR PEDRO II TO THE NORTH OF THE \\ PROVINCE OF RIO DE JANEIRO: POLITICAL DISPUTES IN THE \\ 4TH ELECTORAL DISTRICT (1844/1848)
}

Carlos Eugênio Soares de Lemos ${ }^{1}$

RESUMO: O presente artigo analisa as relações das elites políticas do município de Campos dos Goytacazes com os seus presidentes de província, e, secundariamente, com a Assembleia Legislativa provincial, entre os anos de 1843 e 1848. Baseado em diferentes fontes históricas, tomando como referências as acirradas eleições legislativas de 1844 e a visita do Imperador Pedro II ao Norte da província do Rio de Janeiro, em 1847, procura entender os embates e negociações de tais elites com os governos do conservador João Caldas Vianna (1843/1844) e do áulico-liberal Aureliano de Souza e Oliveira Coutinho (1844/1848). Por fim, conclui que, diferente do papel passivo que lhes reservou a historiografia clássica sobre o período, as elites políticas locais se mostraram atentas às mudanças conjunturais e, por meio da Câmara Municipal e do colégio de eleitores, buscaram garantir os seus interesses políticos e econômicos durante o processo de construção do estado imperial brasileiro.

PALAVRAS-CHAVE: Província do Rio de Janeiro; Política Imperial; Eleições legislativas de 1844

\footnotetext{
* Este artigo é fruto do projeto "De distrito da capitania do Espírito Santo à Província dos Goytacazes: Culturas políticas na vila de São Salvador/ cidade de Campos dos Goytacazes entre os anos de 1820 e 1855", desenvolvido no Laboratório de História Regional do Espírito Santo e Conexões Atlânticas (LACES/UFES) e no Laboratório de História Regional e Patrimônio (LAHIRP/UFF/Campos dos Goytacazes).

1 Professor Associado III do Departamento de Ciências Sociais da Universidade Federal Fluminense/Campos dos Goytacazes, Graduado em História, Doutor em Sociologia, pesquisador do Laboratório de História Regional do Espírito Santo e Conexões Atlânticas (LACES/UFES) e do Laboratório de História Regional e Patrimônio (LAHIRP/UFF/Campos dos Goytacazes). E-mail: eugeniodelemos@hotmail.com
} 
ABSTRACT: This article analyzes the relations of political elites in the municipality of Campos dos Goytacazes with their provincial presidents, and, secondarily, with the provincial Legislative Assembly, between the years 1844 and 1848. Based on different historical sources, taking as references the fierce legislative elections of 1844 and the visit of Emperor Pedro II to the north of the province of Rio de Janeiro, in 1847, seeks to understand the clashes and negotiations of such elites with the governments of the conservative João Caldas Vianna (1843/1844) and the liberal aulic Aureliano de Souza and Oliveira Coutinho (1844/1848). Finally, it concludes that, different from the passive role that the classic historiography reserved for them during the period, the local political elites were attentive to the cyclical changes and, through the City Council and the voters' college, sought to guarantee their political and economic interest during the construction process of the brazilian imperial state.

KEYWORDS: Province of Rio de Janeiro; Imperial Policy; Legislative elections of 1844

\section{Introdução}

As viagens do imperador Pedro II pelos seus domínios são apontadas pelos estudiosos como parte de um plano cujos objetivos eram a unificação das províncias em torno da ideia de nação, o reconhecimento político de sua administração e a garantia da integridade territorial do Império (SCHWARCZ, 1998, p.533; MATTOS, 2009, p.40). Realizadas a partir da década de 40 do século XIX, as visitas feitas às províncias do Sul (1846), ao Norte do Rio de Janeiro (1847), ao Espírito Santo e ao Nordeste (1859) deixaram diversos registros referentes aos preparativos, à estadia e às intrigas políticas que, de certo modo, nos permitem levantar questões, construir uma narrativa e sugerir explicações sobre a relação entre as elites políticas e econômicas locais e os grandes do Império, ou seja, aqueles senhores que, a partir de suas redes de relações, exerciam um poder político que envolvia várias regiões e/ou no âmbito nacional.

Entre 20 de março e 30 de abril do ano de 1847, o Imperador Pedro II, então um jovem de 21 anos, acompanhado de sua comitiva, realizou uma longa viagem pela Província do Rio de Janeiro (FREIRE, 1847). Essa visita se deu num período em que, em meio às disputas partidárias do quinquênio liberal, buscava-se um gabinete que lidasse com a instabilidade política e, em função da 
experiência regencial, superasse os traumas deixados pelas rebeliões das Províncias. A construção do Estado imperial, a constituição da classe senhorial e o processo de consolidação dos partidos estavam em curso (MATTOS, 1987, p. 284). De um lado, os liberais, apelidados de Luzias, e, do outro, os conservadores, chamados de Saquaremas - havendo também os áulicos (palacianos) e os "independentes", isto é, os senhores que se diziam acima das facções existentes ou do espírito de partido que emergia.

Dentre os lugares visitados ao Norte da Província do Rio de Janeiro, aquele no qual o Imperador e o seu séquito mais se demoraram foi em Campos dos Goytacazes, a cabeça do $4^{\circ}$ distrito eleitoral (GOUVÊA, 2008, p.101), cidade na qual ficaram vinte e três dias daqueles quarenta e um em que estiveram a viajar (LEMOS, 2018). Assim, por conta dessa longa permanência, pela abundância das fontes históricas existentes e pelo fato de ser tal município o centro político e econômico da região (GOUVÊA, 2008, p. 32), centralizamos a nossa análise nas intrigas políticas que se desenrolaram nesse local. Afinal, era uma viagem cara que mobilizava muitos recursos materiais e humanos, desencadeava disputas entre as facções políticas e pressionava os moradores em busca de apoio logístico por meio das subscrições, reformas e cuidados com a frente de suas casas, ruas e estradas.

Assim, o presente artigo busca analisar as relações das elites políticas de Campos dos Goytacazes com os seus presidentes de província entre os anos de 1843 e 1848, isto é, João Caldas Vianna (1843/1844) e Aureliano de Souza e Oliveira Coutinho (1844/1848), sendo o primeiro nomeado pelo Gabinete conservador de 23/01/1843, de Carneiro Leão, e o segundo pelo Gabinete de 02/02/1844, de Almeida Torres, fruto de uma aliança dos áulicos com os liberais. Portanto, em última instância, inferimos sobre a dinâmica da participação da elite política local no processo de construção e consolidação do Estado imperial brasileiro.

Em que pese todo um debate pretérito acerca da definição do conceito de elite política, nesse trabalho, partimos do cruzamento daqueles parâmetros que, de modo geral, são utilizados pelos cientistas sociais em sua identificação 
do que seja elite: "positional analysis, reputational analysis, and decisional analysis" (PUTNAM, 1976, p. 15). Então, conectando critérios como a posição assumida pelo sujeito nas instituições formais de governo, o alcance/impacto de suas decisões nesses quadros e a reputação da qual ele gozava no meio social, buscamos identificar os "donos" do poder na esfera local. Para o período que aqui estamos tratando, as elites políticas e econômicas locais convergem em seu perfil, na medida em que os cargos de governança serão exercidos pelos fazendeiros de açúcar, seus familiares, amigos mais próximos e aliados. Ou seja, ainda que houvesse diferenças entre grupos rivais (CARVALHO, 2006, p. 408), grosso modo, partilhavam dos elementos básicos do ideário hegemônico: defesa da propriedade, da manutenção da escravidão e da valorização da agricultura.

A partir de uma abordagem metodológica dialética, procuramos relacionar as restrições impostas pelo contexto com as representações/ações assumidas pelos sujeitos em suas interações, isto é, percebendo que "os homens fazem a sua própria história; contudo, não a fazem de livre e espontânea vontade, pois não são eles quem escolhem as circunstâncias sob as quais ela é feita, mas estas lhes foram transmitidas assim como se encontram" (MARX, 2011, p. 25). Deste modo, buscamos problematizar as disputas e os conflitos ocorridos dentro do campo político local sem perder de vista as limitações impostas pelos condicionantes estruturais. As contradições marcam os processos históricos e, nem sempre, os sujeitos reconhecem as forças econômicas, políticas e culturais a que estão submetidos.

Nesses termos, auxiliados pela Análise dialógica do discurso (ADD), nos pautamos na perspectiva bakhtiniana de que "a relação dialógica é uma relação (de sentido) que se estabelece entre enunciados na comunicação verbal" (BAKHTIN, 1997, p. 346), dependente sempre de três instâncias: o locutor (autor do enunciado), o destinatário (de quem se espera uma compreensão responsiva) e o superdestinatário superior (uma espécie de compreensividade ideal que norteia os falantes) - entendendo que esta última instância "adquire uma identidade concreta variável (Deus, a verdade absoluta, o julgamento da 
consciência humana imparcial, o povo, o julgamento da história, a ciência, etc.)" (BAKHTIN,1997, p. 357). Assim, nos enunciados selecionados, buscamos as relações de sentido que não se limitam às unidades verbais, mas são sustentadas pelas práticas sociais de um contexto histórico específico.

A problematização desse artigo tem por base um corpus discursivo construído a partir de uma seleção operada em diferentes fontes históricas, tais como: ofícios trocados entre as autoridades de diferentes níveis da administração pública, atas da Câmara Municipal e das eleições, listas de subscrições dos moradores, relatórios de presidente de província, jornais, livros da época, legislação e crônicas de viagens. $\mathrm{Na}$ triangulação desse material coletado, elegemos aquelas sequências discursivas formadas por enunciados que, ao nosso ver, apresentavam o melhor potencial para a análise dos sentidos sobre as disputas políticas vivenciadas, revelando as diferentes vozes que circulavam então.

No primeiro tópico, caracterizamos o contexto político institucional da província do Rio de Janeiro, de 1834 a 1847, do ano de sua separação da Corte ao ano em que recebeu a visita do imperador Pedro II. No segundo, retratamos a dinâmica econômica da cidade de Campos dos Goytacazes, destacando as polêmicas em torno da tributação do açúcar e da aguardente, consideradas as suas principais riquezas. No terceiro, abordamos as disputas políticas das diferentes facções locais (liberais, conservadores, "independentes") tendo como referência as tumultuadas eleições de 1844. No quarto, discorremos sobre como, em 1847, a "boa sociedade" local conduziu a recepção de Sua Majestade Imperial. No quinto, analisamos os esforços das elites políticas e econômicas locais em defesa dos seus interesses junto aos "grandes" do Império, assim como as satisfações e insatisfações em torno das graças distribuídas pelo imperador; e, nas considerações finais, tendo em vista a construção da máquina administrativa da província do Rio de Janeiro e a consolidação do estado imperial brasileiro, avaliamos os significados políticos e institucionais da visita realizada por tão importantes autoridades. 


\section{O contexto político da província do Rio de Janeiro (1834-1847)}

Grosso modo, o debate historiográfico em torno do processo de construção do estado imperial se divide entre as abordagens que ressaltam a centralização em mãos do governo geral, situado no Rio de Janeiro (MATTOS, 1987; CARVALHO, 2005; BARMAN, 1988), e aquelas que destacam um papel maior para o poder das províncias, num arranjo em que a dimensão federativa é ressaltada (PEREIRA DE CASTRO, 1972; DOLHNIKOFF, 2005). Nessas bases, partimos do princípio de que adotar as primeiras abordagens não nos impede de considerarmos a relevância das segundas em nossa análise e, assim, também entendemos “o 'Regresso' mais como uma etapa adicional do ajuste entre centro e províncias, em termos da distribuição de poder político, do que como um esmagamento das últimas pelo Rio de Janeiro" (FERRAZ, 2012, p. 32).

Nos anos 40 do século XIX, a disputa entre diferentes projetos para a organização política, administrativa e territorial do estado imperial ainda estava em curso, com sensível vantagem dos defensores da centralização. O Governo havia combatido as chamadas revoltas regenciais, porém, outras se levantaram e foram reprimidas no decorrer da década, como nos casos das Insurreições liberais de Minas Gerais e São Paulo, em 1842, e a Praieira, ocorrida em Pernambuco, no ano de 1848. Portanto, é nesse contexto que podemos pensar a província do Rio de Janeiro como um espaço de experiência, ou melhor, "cumprindo o papel de um laboratório, no qual os Saquaremas tanto testavam medidas e avaliavam ações que buscavam estender à administração geral (MATTOS, 1987, p.253)", considerando-se que servia de referência para outras províncias por conta de sua trajetória histórica, da forte presença dos conservadores e da expansão econômica promovida pelo café a partir da década de 30 .

Dentre algumas de suas inovações, o Ato Adicional de 1834 possibilitou para a província do Rio de Janeiro a criação da Assembleia Legislativa e da Presidência. Até então, por sediar a Corte/capital, a província se encontrava sob 
a administração do Ministério do Império que sobre ela manteve certa ingerência financeira até 1850 (GOUVÊA, 2008, p. 46). Assim, inicialmente, os esforços dos grupos econômicos e políticos, que disputavam o poder, foram para organizar a administração, a justiça, a legislação, as finanças, a polícia, as estatísticas, entre outras instâncias. E, também, buscarem uma sede para o novo governo, a exemplo da pretensão dos senhores da elite de Campos dos Goytacazes de terem a sua cidade como a capital, por acreditarem que, superior a Niterói, "na Província do Rio de Janeiro não se encontra outro local que reúna melhores e tão boas circunstâncias."

O fato é que, não diferente do que vinha ocorrendo na escala política "nacional", muito embora estivessem trabalhando, conjuntamente, nessa organização/funcionamento da máquina pública, os diferentes grupos regionais concorriam entre si para fazerem valer a sua visão sobre o caminho a ser trilhado pela província do Rio de Janeiro. Parecia claro para eles que esse caminho (sobre os limites da autonomia) era crucial para o destino dos municípios, considerando-se que a Lei de $1^{\circ}$ de outubro de 1828 havia dado liberdade as Câmaras de administrarem as suas rendas e, no entanto, "pela Lei das Reformas, esta lhes foi tolhida, e as Câmaras Municipais em seu orçamento de despesa devem apontar tudo que lhes seja necessário dispender, a fim de que a Assembleia Provincial convenha e fiscalize". ${ }^{3}$

Nomeado pelo Imperador e avalizado pelo Conselho de Ministros, o Presidente da província era uma representação do poder central e poderia ser considerado parte da elite nacional (CARVALHO, 2006, p.56). Em certa medida, a sua escolha dependia das disputas políticas que, no período de consolidação do Estado imperial (1840-1853), ocorriam principalmente entre as facções liberais e conservadoras. Nessas disputas, havia também a participação dos que se apresentavam como independentes (supostamente fora do espírito de partido) e aqueles que eram apontados como os áulicos do palácio, a exemplo

2 O Campista, Campos dos Goytacazes/RJ, $\mathrm{n}^{\mathrm{o}}$ 57, p. 01, 30 jul. 1834. In: http://bndigital.bn.gov.br/. Acesso em 20 de jun. 2019.

3 O Recopilador, Campos dos Goytacazes/RJ, $n^{\circ}$ ilegível, 16 mai. 1835. http://bndigital.bn.gov.br/. Acesso em 20 de jun. 2019. 
do grupo que circulava em torno do senador Aureliano de Souza Coutinho e do mordomo da corte, Paulo Barbosa da Silva (PEREIRA DE CASTRO, 1972, p. 512; BENTIVOGLIO, 2010, p.194).

Entre os anos de 1834 e 1847, acompanhando as mudanças que ocorriam nos gabinetes em nível "nacional", diferentes políticos ocuparam o cargo de presidente da província do Rio de Janeiro e entraram em acirradas disputas com os seus opositores para influenciarem as eleições legislativas (provinciais e gerais). No caso, a província era um reduto dos conservadores (MATTOS, 1987, p.252), isto é, "a base eleitoral da oligarquia e uma das principais bases de Honório Hermeto Leão” (PEREIRA DE CASTRO, 1972, p. 523).

Nas eleições para a Assembleia Legislativa provincial de 1834 (contexto de disputa entre liberais moderados, exaltados e caramurus), primeira em que o município de São Salvador dos Campos dos Goytacazes participou como colégio eleitoral da província do Rio de Janeiro, houve uma vitória esmagadora dos moderados, apresentada como resultado do esforço de "homens que prezam de coração a sua Pátria e que não a desejam ver entregues à discrição de homens violentos que não sabem guardar meio termo das coisas."4 Como se vê, trata-se de um enunciado em que o sentido aponta para a existência de uma única facção equilibrada, pois, de um lado, encontravam-se a anarquia e o autoritarismo dos violentos liberais exaltados e caramurus; do outro, a ordem e a bem entendida liberdade dos moderados com o seu bom senso. No contexto dos anos 40, essa tônica dialógica da "ordem versus desordem", do suposto equilíbrio dos conservadores no poder ${ }^{5}$, percorrerá muitos textos/discursos que os centralistas farão circular em seus periódicos locais. Sendo que, por outro lado, também os luzias farão circular sentidos em que se colocavam como os defensores da verdadeira liberdade e contra a opressão dos seus opositores, representantes das oligarquias centralizadoras.

\footnotetext{
4 O Campista, Campos dos Goytacazes//RJ, $\mathrm{n}^{\mathrm{o}}$ 90, 03 de dez 1834. In: http://bndigital.bn.gov.br/. Acesso em 20 de jun. 2019.

${ }_{5}^{5}$ O Monitor Campista, Campos dos Goytacazes/RJ, n 119, p. 02, 28 out. 1847. In: Arquivo Nacional - Ministério da Justiça e Segurança Pública.
} 
Assim, não perdendo de vista que o município de Campos dos Goytacazes era um forte reduto dos regressistas/ conservadores havia certo tempo, escolhemos as eleições de 1844 para analisarmos alguns aspectos das relações entre as elites políticas locais, os seus presidentes e, secundariamente, com a Assembleia Provincial Legislativa. Nelas, um ex-presidente considerado conservador, como era o caso de João Caldas Vianna, natural da cidade, disputava com o seu sucessor, Aureliano do Souza Coutinho, um áulico apoiado por liberais, a eleição de suas respectivas chapas na região. Na realidade, por trás dessa disputa devemos também considerar o aumento dos ataques dos conservadores a Aureliano desde a saída de Honório Hermeto Leão do cargo de chefe do Gabinete. Depois de ter derrotado os palacianos numa disputa de indicação de senador para uma vaga no Rio de Janeiro, Honório solicitou do imperador a demissão de Saturnino, irmão de Aureliano, do cargo de inspetor da alfândega. Diante da recusa de Pedro II, Honório, considerado um homem ríspido e de pouca cortesia, apresentou o seu próprio pedido de demissão (PEREIRA DE CASTRO, 1972, p.520).

Portanto, foi um momento rico em que os conflitos entre as facções trouxeram à tona diferentes dimensões das relações de João Caldas e Aureliano numa escala geral e, também, com a sua rede de apoio local - na cidade de Campos dos Goytacazes. Ambos mediam forças no distrito mais rico do interior da Província, nas primeiras eleições legislativas, logo após o Decreto de 04 de maio de 1842, “cuja principal inovação foi a qualificação prévia dos votantes e dos elegíveis por uma junta composta do juiz de paz, do pároco e da autoridade policial” (NUNES LEAL, 1993, p. 207). E a novidade sobre esse decreto em questão era que "o juiz de paz, que representava o elemento popular; o subdelegado de polícia, fiscal do governo encarregado de manter a ordem e a regularidade do processo eleitoral; o pároco, entidade neutra entre $\mathrm{o}$ representante do povo e o do poder" (SOUZA, 1979, p. 58).

Ainda que amparados pela lei, a ingerência dos governos central e provincial nas eleições não se dava de forma automática e sem sofrer alguma resistência, dependia sempre da habilidade política dos grandes do Império em 
fazerem concessões para obterem, em troca, algum tipo de adesão e agência dos senhores e moradores locais. É fato que a partir da lei de $1^{\circ}$ de outubro de 1828 , as Câmaras Municipais foram esvaziadas do poder que exerceram no período colonial (GOUVÊA, 2008, p.111; DOLHNIKOF, 2005, p.204), principalmente, se levarmos em consideração o aumento das atribuições da Assembleia Provincial propostas pelo Ato Adicional, de 1834. Muito embora fosse uma redução do poder local, não representava, em absoluto, uma paralisia para os "homens bons" da cidade que ainda podiam contar com o peso dos votos de seu colégio eleitoral. E, em 1841, na batalha sobre o dízimo do açúcar, os políticos do Império estavam cientes desse poder de barganha dos senhores do açúcar:

"Pedem-nos que declaremos que votaram contra o imposto aos fabricantes de açúcar decretado pela Assembleia Provincial do Rio de Janeiro os Srs. Rodrigues Torres, Vianna, Azambuja, Pereira da Silva, Caldas Vianna, Alves Carneiro, Cesar Menezes e Azevedo."

A relação das elites políticas locais com os deputados da Assembleia Provincial nem sempre foi amigável, dependendo sempre da força ideológica e alianças que imperavam na casa legislativa em cada momento, como no exemplo da antipatia nutrida pelos conservadores locais contra o liberal Manoel José de Souza França. Volta e meia, esse deputado fazia algum comentário depreciativo sobre as pretensões dos senhores de Campos dos Goytacazes, como quando ele se posicionou contrário à construção de um Liceu provincial na cidade com a seguinte colocação: tão grande tendência para as letras tem porventura a juventude campista? E ainda quando a tivesse, eu lhes diria devagar, que não queremos nós e nem devemos querer uma república de bacharéis. ${ }^{7}$ Como se vê, é possível explorarmos como um dos sentidos do enunciado o fato de a carreira das letras ser uma posição disputada entre os grupos e classes no meio social e, ao mesmo tempo, inferirmos sobre a rixa

\footnotetext{
${ }^{6}$ O Monitor Campista, Campos dos Goytacazes/RJ, 28 mai. 1841, n.116. In: Arquivo Público Municipal Waldir Pinto de Carvalho, Campos dos Goytacazes.

7 Diário do Rio de Janeiro, Rio de Janeiro, 22 de março de 1843, $\mathrm{n}^{\circ}$ 66. In: http://bndigital.bn.gov.br/. Acesso em 30 de jun. 2019.
} 
política/partidária de um deputado com uma cidade que pouco lhe apoiara na época em que fora presidente da província (1836-1840). ${ }^{8}$

De certo modo, nos periódicos locais, circulavam representações que colocavam a Assembleia Provincial como a grande responsável pela sobrecarregada tributação vivenciada pelos taverneiros e pequenos produtores. ${ }^{9}$ No entanto, devemos ressaltar que os deputados comprometidos com os interesses da região tinham como objetivo, principalmente, a defesa do açúcar e, em especial, dos grandes produtores. Por mais que houvesse reclamações sobre a assimetria que penalizava o município em sua relação com os governos provincial e geral, reconhecendo os limites legais impostos às Câmaras Municipais pela nova ordem que se instalara com a Monarquia, não devemos imaginar que os senhores da política local tenham se tornado personagens passivos dos grandes do Império, conformados ao papel de figurante que thes estava reservado, mesmo porque, como veremos mais adiante, no exemplo de 1844, "as eleições testavam e ostentavam a liderança do chefe local" (GRAHAM, 1997, p.16).

\section{As elites do açúcar ao Norte da Província}

Ao longo do século XIX, ao norte da Província do Rio de Janeiro, a cidade de Campos dos Goytacazes ocupou a posição de centro político e econômico regional. Essa primazia era garantida pelo número de votos de seu colégio eleitoral, pelo capital político das elites locais, das alianças de seus representantes no legislativo provincial e, sobretudo, pela riqueza resultante da produção de açúcar e aguardente (LEMOS, 2018 b, p. 236). Esses produtos estavam conectados ao comércio de cabotagem capitaneado pelos grandes negociantes da praça do Rio de Janeiro, desde as últimas décadas do século

\footnotetext{
${ }^{8}$ O Monitor Campista, Campos dos Goytacazes/RJ, 20 abr. 1841, n.105. In: Arquivo Público Municipal Waldir Pinto de Carvalho, Campos dos Goytacazes.

${ }^{9}$ O Monitor, Campos dos Goytacazes/RJ, 28 set. 1839, n.123. In: http://bndigital.bn.gov.br/. Acesso em 30 de jun. 2019.
} 
XVIII (FARIA, 1985, cap. III, p. 07; FRAGOSO, 1998, p. 361; SILVEIRA, 2013, p. 80).

Em termos de arrecadação para os cofres provinciais, com uma população de aproximadamente 66 mil habitantes, média inferida entre os anos de 1844 e $1850,{ }^{10}$ Campos dos Goytacazes foi a cidade que, no período aqui selecionado, 1844 a 1848, mais concorreu para o orçamento da receita da província do Rio de Janeiro com uma contribuição média anual de 42:271\$852 (quarenta e dois contos, duzentos e setenta e um mil e oitocentos e cinquenta e dois réis). Essa contribuição era acompanhada apenas pela cidade de Niterói, capital da província, a única que do Norte se aproximava em termos de arrecadação com a quantia média anual de 33:060\$102 (trinta e três contos, sessenta mil e cento e dois réis). ${ }^{11}$

Portanto, sendo o maior orçamento da província, a receita prevista para o município de Campos, entre outubro de 1846 e setembro de 1847, foi de 20:736\$838. ${ }^{12}$ Segundo Gouvêa (2008, p. 39), ao longo do século XIX, essa prevalência orçamentária de Campos se deu por conta de o município não recolher o dízimo do açúcar para os cofres da província, mas, sim, para o seu próprio cofre. Essa afirmação precisa ser relativizada para o período que aqui estamos retratando, considerando-se que o imposto em questão já não era recolhido, muito embora o município arrecadasse uma boa quantia com o imposto do encaixe do açúcar que vigorava desde a lei provincial de 3 de janeiro de $1837 .{ }^{13} \mathrm{E}$ os impostos que privilegiavam os grandes fazendeiros não

\footnotetext{
${ }^{10}$ Não ignorando o quanto eram imprecisos tais números, essa média foi obtida a partir dos levantamentos feitos entre 1844 e 1850 e que constam nos mapas estatísticos da população da província do Rio de Janeiro que se encontram nos relatórios dos presidentes de província. Disponível em: $\quad$ http://ddsnext.crl.edu/titles $/ 184 \#$ ? $\mathrm{c}=4 \& \mathrm{~m}=0 \& \mathrm{~s}=0 \& \mathrm{cv}=0 \& \mathrm{r}=0$ \&xywh=532\%2C-111\%2C3143\%2C2217. Acesso em 15/06/2019.

${ }^{11}$ Média obtida a partir da tabela demonstrativa do orçamento da receita da Província do Rio de Janeiro presentes nos relatórios dos presidentes entre os anos de 1844 e 1848. Arquivo Público do Estado do Rio de janeiro. Disponível em: http://ddsnext.crl.edu/titles $/ 184 \#$ ? $\mathrm{c}=4 \& \mathrm{~m}=0 \& \mathrm{~s}=0 \& \mathrm{cv}=0 \& \mathrm{r}=0 \& \mathrm{xywh}=-532 \% 2 \mathrm{C}-$ 111\%2C3143\%2C2217. Acesso em 15/06/2019.

${ }^{12}$ Almanak Laemmert Administrativo, Mercantil e Industrial da Corte e da Província do Rio de Janeiro, 1847, Suplemento, p. 18. In: http://bndigital.bn.br/acervo-digital/almanakadministrativo-mercantil-industrial-rio-janeiro/313394. Acesso em 30 jun. 2019.

${ }_{13}$ Monitor Campista, Campos dos Goytacazes, RJ, 8 fev. 1848, n.14. In: Arquivo Público Municipal Waldir Pinto de Carvalho, Campos dos Goytacazes.
} 
concorriam automaticamente para o enriquecimento dos outros segmentos produtivos. Eram recorrentes as reclamações dos representantes dos lavradores e pequenos produtores nesse sentido:

Nós vemos que os ricos proprietários de fazenda de açúcar são, no nosso país, aqueles que nada pagam de direito ao município que habitam. Seus gêneros não são vendidos no país, e por isso não se acham obrigados a lei dos impostos que mandam o encaixador da cidade contribuir com 300 rs por caixa e 100 rs por feixe ou barrica, ao passo que o pobre e principiante lavrador se acha sujeito ao pagamento de $12 \$ 800$ rs por cada um de seus carros que entrar na cidade, e 300rs por cada uma caixa, porque o comércio calcula as despesas que tem a fazer quando compra gênero ao lavrador. ${ }^{14}$

O dízimo do açúcar passou por algumas mudanças ao longo da primeira metade do século XIX. Inicialmente, era cobrado pelas rendas gerais (nacionais), mas com a lei de 31 de outubro de $1835,{ }^{15}$ foi transferido para a alçada das rendas provinciais que, no caso específico do Rio de Janeiro, ficou estabelecido em $5 \%$ o valor de sua arrecadação. Posteriormente, essa lei foi abolida e, logo depois, uma nova lei orçamentária da província estabeleceu o valor de 2\%. A pedido da Câmara municipal de Campos à Assembleia legislativa provincial, esse valor, considerado irrisório, também foi abolido pela lei $n^{\circ} 284$ de $1843^{16}$ junto com o imposto de patentes sobre engenhos e engenhocas. Diante desta última determinação, muitos fazendeiros do município que estavam devendo esse imposto, o de patentes, entenderam que não precisavam mais pagá-lo, quer dizer, resolveram não saldar a dívida que possuíam com os cofres da província. ${ }^{17}$

$\mathrm{Na}$ ocasião, as tradicionais famílias - proprietárias de terras, escravos e produtoras de açúcar e/ou negociantes - dividiam o domínio político da região e

14 Monitor Campista, Campos dos Goytacazes, RJ, 28 set. 1839, n.123. In: http://bndigital.bn.gov.br/. Acesso em 30 de jun. 2019.

${ }^{15}$ Brasil. Lei de 31 de outubro de 1835. Coleção de Leis do Império do Brasil. Rio de Janeiro: Tipografia Nacional, 1864. - Essa lei estabelecia a divisão de rendas entre o Governo geral e as Províncias, ficando com esta todas as rendas que não constassem no rol daquelas. Assim, as províncias deveriam legislar sobre elas, a exemplo do açúcar.

${ }^{16}$ Correio Oficial da Província do Rio de Janeiro, Rio de Janeiro, p.01, 28 mai. 1843. In: http://bndigital.bn.gov.br/. Acesso em 30 de jun. 2019.

${ }_{17}$ Monitor Campista, Campos dos Goytacazes, RJ, n.80, 17 jul. 1845. In: Arquivo Público Municipal Waldir Pinto de Carvalho, Campos dos Goytacazes. 
faziam pressão em defesa dos seus interesses. Dentre essas famílias históricas, ${ }^{18}$ "fonte importante de capital político" (GRAHAM, 1999, p. 04), o sobrenome Vianna se destacava justamente por ocupar cargos em diferentes escalas. O patriarca, o capitão Paulo Francisco da Costa Vianna, figura ativa na elite política local, enviara os filhos para estudarem em Coimbra, provavelmente, com o objetivo de que, mais tarde, todos conseguissem um posto na carreira das letras. No topo da pirâmide, encontrava-se o filho Joaquim Francisco Vianna, matemático, que era ministro da fazenda do $3^{\circ}$ gabinete cujo organizador fora Honório Hermeto Carneiro Leão. Por sua vez, bacharel em direito, João Caldas Vianna era presidente da província e, tendo sido deputado e vice-presidente, fora nomeado ao cargo com a ajuda do irmão ministro da fazenda mas, também, por ser bem quisto pela cúpula conservadora. ${ }^{19}$ Por fim, gozando do apoio dos seus dois irmãos, o bacharel em direito, José Francisco Vianna, exercia a função de coletor de rendas geral e provincial no município de Campos dos Goytacazes e São João da Barra - ou seja, era o homem responsável pela cobrança dos tributos, cargo que já ocupara em anos anteriores sob a acusação de obtê-lo com "nomeação tristíssima, arrancada a patronato tão escandaloso",20

Os irmãos pertenciam à facção conservadora e, em diferentes escalas, possuíam uma rede de poderosos aliados espalhados em cargos estratégicos na administração pública, situação a que a oposição chamava de afilhadagem, sendo eles afilhados dos maiores e padrinhos dos menores. ${ }^{21} \mathrm{E}$ também possuíam inimigos, tendo o número destes aumentado quando, por conta de uma querela sobre heranças, a família entrou em guerra com a irmandade da Santa Casa de Misericórdia de Campos dos Goytacazes, ofendendo os "homens

\footnotetext{
${ }^{18}$ Há várias famílias que, ao longo do tempo, estiveram presentes na ocupação dos cargos de mando na esfera local. Assim, o poder veio passando de geração para geração, como nos exemplos das famílias Costa Viana, Pereira Baptista, Matos Pimenta, Ribeiro de Castro, Gomes Barroso, Nunes Pereira, Carneiro da Silva, Andrade Almada, para citar algumas.

19 O Novo Tempo- folha política e literária, Rio de Janeiro, nº 16, p. 02, 11 abr. 1844. http://bndigital.bn.gov.br/. Acesso em 30 de jun. 2019.

20 Monitor Campista, Campos dos Goytacazes/RJ, $\mathrm{n}^{\mathrm{o}}$ 52, p. 02, 02 out. 1840. http://bndigital.bn.gov.br/. Acesso em 30 de jun. 2019.

${ }^{21}$ Farol Constitucional, Rio de Janeiro, n 90, 07 nov. de 1843. In: http://bndigital.bn.gov.br/. Acesso em 06 de jul. 2019.
} 
bons" da instituição com a alcunha de "cambada de patifes". ${ }^{22}$ De qualquer modo, por ser a família vinculada à Sociedade Campista de Agricultura, ${ }^{23}$ é possível inferir que os Vianna fizeram vista grossa para a dívida dos produtores inadimplentes, principalmente depois de o presidente João Caldas Vianna ter sancionado, em 08 de maio de 1843, o Decreto $n^{\circ} 284$, responsável pela extinção do imposto de patentes sobre os engenhos de açúcar e a cota do dízimo do mesmo. ${ }^{24}$

Contudo, o alívio tributário não durou muito tempo para os senhores de engenho endividados. No governo seguinte, sob a presidência de Aureliano Coutinho de Oliveira (1844-1848), sucessor de João Caldas Vianna, a administração da fazenda exigiu que o novo coletor provincial, Bernardino José Maciel, um intermediário, homem de confiança do novo presidente, cobrasse dos senhores de engenho as dívidas que ficaram esquecidas no passado recente e que as mesmas fossem pagas com todas as correções previstas pela lei. Importante destacar que, tendo sido colocado à venda, o direito de cobrar essas dívidas foi comprado pelo novo fiscal. Assim, no caso daqueles senhores endividados que se recusassem a pagar, a orientação dada foi para que se agisse "imediatamente contra eles, procedendo a necessária penhora que garanta a dívida provincial e remetendo imediatamente a relação de tais coletados". 25

Somado a essa determinação, havia a acusação de que o ex-coletor, José Francisco Vianna, não teria repassado os últimos impostos arrecadados para os cofres da província. ${ }^{26}$ Ademais, as ações do governo não se restringiram à cobrança dessas dívidas passadas. A medida mais almejada era a do reestabelecimento do extinto dízimo do açúcar, assunto ao qual Aureliano

\footnotetext{
${ }^{22}$ Farol Constitucional, $\mathrm{n}^{\mathrm{o}}$ 38, 04 fev. de 1843. In: http://bndigital.bn.gov.br/. Acesso em $06 \mathrm{de}$ jul. 2019. Obs: na ocasião, faziam parte da instituição importantes proprietários e negociantes e tinha como presidente Domingos Gomes Barroso.

23 Monitor Campista, Campos dos Goytacazes/RJ, 23 set. de 1842. In: Arquivo Público Municipal Waldir Pinto de Carvalho, Campos dos Goytacazes.

${ }^{24}$ Correio Oficial da Província do Rio de Janeiro, 28 mai. 1843, p.01. In: http://bndigital.bn.gov.br/. Acesso em 06 de jul. 2019.

${ }^{25}$ Monitor Campista, Campos dos Goytacazes/RJ, 10 jul. 1845, n.77, p.3. In: Arquivo Público Municipal Waldir Pinto de Carvalho, Campos dos Goytacazes.

${ }^{26}$ Diário do Rio de Janeiro, Rio de Janeiro, 01 ago. 1844, n. 6680, p.1. In: http://bndigital.bn.gov.br/. Acesso em 06 de jul. 2019.
} 
retornava sempre que encontrava um espaço em seus pronunciamentos sobre o equilíbrio financeiro provincial. Essa demanda de retomada do imposto foi motivo de sérias controvérsias entre os deputados provinciais, o presidente e parte dos produtores de açúcar da região. E aqui cabe um parêntese, pois a elite política local, isto é, aqueles que ocupavam cargos de governança, há muito vinha sendo acusada pelos lavradores, pequenos produtores, taverneiros e comerciantes locais de protegerem os interesses dos ricos proprietários de fazenda de açúcar. $^{27}$ E o porta voz de tais reclamações, em 1839, era o periódico $O$ Monitor, pertencente a Bernardino José Maciel, o mesmo que, alguns anos depois, viria a se tornar o braço direito de Aureliano na região e bem relacionado com os grandes produtores a quem criticava.

Para todos os envolvidos na disputa, fazer valer os seus interesses dependeria de que seu grupo político obtivesse um bom número de cadeiras nas Assembleias Geral e Provincial, votos que, na cidade de Campos viriam das listas compostas por aqueles mesmos nomes que ocupavam posição de destaque no Senado da Câmara, na administração pública, no tribunal do júri, na Guarda Nacional, nas ordens terceiras e na Santa Casa de Misericórdia. ${ }^{28}$ E, por fim, no caso de Aureliano, em especial, havia os "seus reiterados esforços para constituir uma base política autônoma na província do Rio de Janeiro" (FERRAZ, 2012, p. 85) que era dominada pelos conservadores. Com o fim do Gabinete conservador de 23 de janeiro de 1843, de Honório Hermeto Carneiro Leão, houve a dissolução da legislatura existente, a convocação de uma nova Assembleia e a nomeação de Aureliano ao cargo de presidente de província como uma resposta do novo Gabinete ao exclusivismo partidário dos conservadores ( PEREIRA CASTRO, 1972, p. 523).

\section{As "tumultuadas" eleições de 1844}

\footnotetext{
${ }^{27}$ O Monitor, Campos dos Goytacazes/RJ, 28 set 1839, nº 123. In: http://bndigital.bn.gov.br/. Acesso em 06 de jul. 2019.

28 O Monitor Campista, Campos dos Goytacazes/RJ, 06 nov. 1840, n n 62 . In: http://bndigital.bn.gov.br/. Acesso em 06 de jul. 2019.
} 
Fruto da aliança dos palacianos com os liberais, o Gabinete, de 02 de fevereiro de 1844, nomeou Aureliano de Souza Coutinho ao cargo de Presidente da província do Rio de Janeiro, tendo este tomado posse no dia 12 de abril de 1844. Esse palaciano, ${ }^{29}$ que fora tutor do imperador Pedro II e organizara os dois primeiros gabinetes após 1840, havia sido afastado do poder por um artifício dos regressistas que o acusavam de ser favorável aos interesses britânicos e de encobrir o "fracasso" do seu irmão, Saturnino de Souza e Oliveira Coutinho, na luta contra os farroupilhas no Sul do Brasil. (CASTRO, 1972, p. 515). Assim, entre os diversos desafios que ele tinha pela frente estava o de garantir um alicerce político na província do Rio de Janeiro que, por razões históricas, era um terreno onde ex-presidentes conservadores como Rodrigues Torres, Paulino de Souza e Carneiro Leão tinham construído as suas bases de apoio. Então, desse modo, Aureliano teria condições de melhor governar e de fortalecer a sua posição no jogo político provincial/nacional, considerando-se que o seu irmão, Saturnino de Souza, havia sido derrotado na província do Rio de Janeiro em quatro eleições consecutivas: 1836, 1840, 1842 e 1844 . $^{30}$

Um colégio eleitoral no qual se mostrava viável a retomada de Aureliano era o do Norte da província e, em especial, no da cidade de Campos dos Goytacazes. Muito embora se tratasse de uma região em que era forte a defesa da centralização, havia ali também um importante reduto favorável à descentralização. Logo após a Abdicação de Pedro I, alguns embates ocorreram, resultando no assassinato de um conhecido liberal moderado, o médico jornalista Francisco José Alypio, cuja suspeita do crime recaiu sobre os liberais exaltados (LEMOS, 2017). Portanto, na terra natal e base política do conservador João Caldas Vianna, nas eleições para deputados gerais, em 1840, Aureliano Coutinho também teve uma boa votação. Ele e Joaquim Francisco Vianna tinham sido os mais votados, com 71 e 70 votos, respectivamente, acompanhados de perto por regressistas como Paulino José Soares de Souza,

\footnotetext{
${ }^{29}$ Bacharel em direito, Aureliano era um militar que já tinha exercido o cargo de diplomata, político de projeção nacional, era também jornalista e fazia parte do grupo seleto com acesso ao imperador Pedro II e que participara de sua formação.

30 O Brasil - vestra res agitur, Rio de Janeiro, nº526, 16 abr. 1844. In: http://bndigital.bn.gov.br/. Acesso em 12 de jul. 2019.
} 
Joaquim José Rodrigues Torres e Salvador José Maciel. ${ }^{31} \mathrm{Na}$ ocasião, ele, Aureliano, ainda era visto pelos regressistas locais como um defensor da centralização que havia trabalhado pelo projeto da maioridade de Pedro II. No entanto, em 1844, numa outra conjuntura política, a percepção sobre o áulico senador já não era tão boa quanto antes, pelo contrário:

Sabia o ministério, como todo o Império, que o Sr. Aureliano fez cair o gabinete de 23 de julho para ser seu irmão nomeado presidente do Rio Grande; fez cair o de 23 de março por não ter o Sr. Saturnino saído eleito deputado por esta província; atribuindo esta derrota a poucos esforços de membros daquele (...) O Sr. Aureliano não pode mascarar sua hipocrisia por muito tempo, e as violências e arbitrariedades de todo o gênero tem posto a descoberto o ódio que nem mesmo a S. Ex. procura já ocultar. ${ }^{32}$

A disputa entre as facções políticas sobre o sentido do governo tinha na imprensa um de seus braços fortes. Grosso modo, a partir de 1844, sustentando o discurso em defesa de um estado forte, centralizado e de uma política liberal representativa, o periódico O Monitor Campista firmou-se como o porta voz dos conservadores; o Diário Comercial de Campos, fazendo duras críticas à dimensão oligárquica e despótica dos “ordeiros”, era apontado por estes como o representante dos luzias e dos aureliânicos; e, por sua vez, O Provinciano amigo da monarquia e do governo era um jornal de ocasião, criado pelos partidários de Aureliano com a justificativa de que era dever do cidadão amante do país "armar-se também com a imprensa, e defendendo o governo inutilizar os tiros dessa oposição frenética e delirante, fazendo que as ervadas e peçonhentas setas que ela dispara não envenenem a opinião pública". ${ }^{33}$ Enfim, uma guerra de narrativas era travada pelos jornais, nos quais as facções se apresentavam como enunciadoras de uma verdade, os assinantes como coenunciadores responsivos na adesão a essa verdade, e a Monarquia

\footnotetext{
${ }^{31}$ O Monitor Campista, Campos dos Goytacazes/RJ, n467, 24 nov. 1844. In: Arquivo Público Municipal Waldir Pinto de Carvalho, Campos dos Goytacazes.

${ }^{32}$ O Monitor Campista, Campos dos Goytacazes/RJ, n 436,30 ago. 1844. In: Arquivo Público Municipal Waldir Pinto de Carvalho, Campos dos Goytacazes.

${ }_{33}$ O Novo Tempo- Folha Política e Literária, no 64, Rio de Janeiro, 17 out. 1844. In: http://bndigital.bn.gov.br/. Acesso em 12 de jul. 2019.
} 
Constitucional cumpria a função de superdestinatário ideal de como o mundo deveria ser.

Ora, com a queda do gabinete de 23 de janeiro de 1843 e a subida do ministério de 02 de fevereiro de 1844, no previsível efeito dominó que marcara a política imperial, as exonerações, transferências e nomeações aconteceram por todos os cantos. Devemos considerar que, desfeita a Assembleia Geral, as eleições gerais e provinciais se tornaram o foco de todos, sendo necessário que os cidadãos alinhados com o novo Gabinete e o presidente da província estivessem nos lugares certos para fazerem funcionar as eleições a favor do grupo que, agora, ocupava o poder. Na província do Rio de Janeiro, esse movimento de dança das cadeiras foi apelidado pelos opositores do governo de "a explosão do vapor Aureliano".

No caso da cidade de Campos dos Goytacazes, as decisões tomadas pelo novo Gabinete e Governo provincial atingiram o grupo conservador que apoiava os Vianna. A começar pelo próprio ex-presidente João Caldas que, na condição de bacharel em direito, foi transferido para exercer o posto de delegado no Rio Grande do Sul; o seu irmão, José Francisco, foi destituído do cargo de coletor da província; e membros de outras famílias das primeiras casas da cidade foram desempossados, a exemplos dos ricos proprietários e coronéis da Guarda Nacional como Francisco de Paula Barroso, José de Brito Ribeiro, Manuel Joaquim Pereira Baptista, só para citarmos alguns. Aconteceram cerca de trinta demissões que envolviam membros da Guarda Nacional, delegado, subdelegados, coletores, fiscais, presidentes de comissões e juízes de direito da extensa rede dos que se diziam os maiores defensores da ordem. ${ }^{34}$

Por outro lado, um novo grupo, também composto de elementos da classe senhorial, comerciantes e bacharéis, foi alçado ao poder como o proprietário Gregório Francisco de Miranda (comandante da Guarda Nacional), o comerciante Bernardino José Maciel (coletor), os proprietários João Bernardo de Andrade e Almada (delegado), Joaquim Ribeiro de Castro (subdelegado),

\footnotetext{
${ }^{34}$ O Monitor Campista, Campos dos Goytacazes/RJ, no 446, 04 out. 1844. In: Arquivo Público Municipal Waldir Pinto de Carvalho, Campos dos Goytacazes.
} 
José Antônio Pimenta Bueno (promotor), bacharel João de Souza Nunes Lima (juiz municipal), entre outros. Muitos desses homens se viam tão monarquistas, liberais e defensores da ordem como os adeptos do clube conservador. Tratavase de um momento em que os partidos ainda estavam em formação/consolidação. Assim, se havia clareza para alguns cidadãos sobre a que facção pertenciam, para outros, o pertencimento oscilava em função das possibilidades que se abririam com a chegada de um novo grupo ao poder. ${ }^{35} \mathrm{E}$, para todos, ainda que alguns ignorassem, o mundo da política não funcionava de acordo com a vontade pessoal dos poderosos locais, dependendo sempre dos limites estruturais impostos pela ordem legal e alianças estabelecidas nos patamares mais altos da política nacional.

Portanto, fosse saquarema ou luzia, o discurso parecia convergir em defesa desse superdestinatário ideal que era uma monarquia pautada na ordem e na bem entendida liberdade. Porém, não devemos confundir essa bem entendida liberdade com a defesa do federalismo, pois essa era uma bandeira que trazia muitas discórdias dentro e entre grupos (CARVALHO, 2005). De qualquer modo, os conservadores acusavam os governistas (que eles entendiam como liberais e áulicos, muito embora houvesse conservadores entre eles) de tramarem com os ingleses pelo fim da mão de obra escrava, de jogarem os pobres contra os ricos, de ressuscitarem o dízimo do açúcar, enfim, de levarem à frente a temerosa afirmação feita pelo Sr. Paula Souza no Senado, "que o carro da revolução não tinha cessado sua carreira". ${ }^{36}$ Então, se era assim, o que a "boa sociedade" local poderia esperar da política num futuro próximo? Para o partido da ordem, o caos e a anarquia das rebeliões que resultaram da experiência de descentralização da década anterior e que, em razão da anulação das "eleições do cacete", as revoltas liberais de Minas Gerais e São Paulo, em 1842 , tentaram reviver.

\footnotetext{
${ }^{35}$ Um bom exemplo disso é o caso do senhor José Martins Pinheiro, futuro barão da Lagoa Dourada, cuja trajetória demonstra bem essa movimentação entre a liberdade e a ordem, de defensor da descentralização, em 1834, a ferrenho amante da ordem no final dos anos 40.

${ }^{36}$ Monitor Campista, Campos dos Goytacazes/RJ, n²48, 11 out. 1844. In: Arquivo Público Municipal Waldir Pinto de Carvalho, Campos dos Goytacazes.
} 
Em 07 de setembro de 1844, nas eleições para vereador e juiz de paz, em Campos dos Goytacazes, o grupo de apoio ao governo de Aureliano levou a melhor nas mesas paroquiais compostas pelas freguesias de Santo Antônio de Guarulhos, São Salvador, Santa Rita, São Sebastião, São Gonçalo, São Fidélis e Curato de Aldeia da Pedra. Dos nove vereadores eleitos, cinco eram da base governista (José Martins Pinheiro, 1526 votos; João Bernardo de Andrada e Almada, 1466 votos; Agostinho do Santos Collares, 1361 votos; Julião Ribeiro de castro, 1346 votos; Bernardino José Maciel, 1212 votos), três independentes (Lourenço José de Araújo, 1044 votos; João José Martins Leão, 970 votos, Bento Benedito de Almeida Baptista, 854 votos) e um fazia oposição aberta a Aureliano (José Francisco Vianna, 1365 votos). ${ }^{37}$ No caso dos juízes de paz, cada freguesia elegia os seus quatro e, entre eles, era possível encontrar alguns dos vereadores mais votados, como foram os casos de José Martins Pinheiro, Julião Ribeiro de Castro e Agostinho Collares. Em pesquisa exploratória sobre as eleições para vereador, juiz de paz e eleitores entre os anos de 1836 e 1848 , observamos que os nomes/sobrenomes se repetem ou se revezam nas posições de representação e governança, não raro, passando entre diferentes gerações dentro das mesmas famílias históricas que ocuparam o poder.

Ao analisarmos o perfil socioeconômico dos eleitos, em 1844, a maioria era da classe senhorial do açúcar ou ligada a ela por consanguinidade, vinda de famílias tradicionais como as do Vianna, Ribeiro de Castro, Almeida Baptista, Pereira da Silva etc. A exceção era Bernardino José Maciel que, não sendo natural da cidade, tinha a propriedade de um armarinho e de um alambique, tendo se transformado numa dessas "notabilidades de aldeia" (CARVALHO, 2006, p.399). Por ter se tornado o homem de confiança e agenciador eleitoral de Aureliano na região, acumulava os cargos de coletor provincial e geral, chefe da Guarda Nacional, substituto de juiz, entre outros. ${ }^{38}$ Era uma figura detestada pela ala mais radical dos conservadores e pelos fazendeiros endividados, sendo

\footnotetext{
${ }^{37}$ Monitor Campista, Campos dos Goytacazes/RJ, nº442, 20 set. 1844. In: Arquivo Público Municipal Waldir Pinto de Carvalho, Campos dos Goytacazes.

${ }^{38}$ Pela ausência de fontes não é fácil rastrear como se deu a aproximação entre ele e Aureliano. Nas fontes com as quais trabalhamos a relação já se apresentava como constituída.
} 
apelidado de Petrus in cunclis ou fac totum ${ }^{39}$ Em que pesassem as ironias sobre a sua origem de classe, acúmulo de cargos públicos e dificuldade de se expressar em público, dentre as principais razões para essa oposição estavam os fatos de ele ter ressuscitado a ideia de cobrar o dízimo do açúcar e de tratar com rigor extremado os demais impostos.

Então, em 1844, para a eleição dos eleitores que deveriam votar para as Câmaras Legislativas, um grupo de senhores enviou ao presidente da província uma representação na qual solicitava o afastamento do juiz de paz, Baltazar Caetano Carneiro, sob a acusação de que o mesmo cometera faltas contra a legislação eleitoral, como a de não ter afixado na porta da igreja matriz a lista de eleitores dentro do prazo exigido. ${ }^{40}$ Os "ordeiros" saíram em defesa da honra do juiz, considerando que, embora não fosse bacharel em direito, além de ser querido pela "boa sociedade", ele era um homem com uma longa lista de serviços prestados à municipalidade. De pouco adiantou o discurso sobre a trajetória histórica do acusado, Aureliano acatou a acusação e afastou o juiz da organização das eleições para deputados. Por sua vez, de maioria aureliânica, tendo à frente o vigário Antônio José da Silva Pessanha, ${ }^{41}$ a nova junta formadora da lista geral de votantes colocou em dúvida se o ex-presidente, João Caldas, poderia votar e ser votado na freguesia de São Salvador, considerandose que há certo tempo residia em Niterói. ${ }^{42}$

O fato é que, como era recorrente, em meio a tantas controvérsias, nas eleições para eleitores foram escolhidos 91 nomes que eram, em sua grande maioria, parte e/ou ligados às grandes famílias da classe senhorial do açúcar, proprietários de terras e de escravos, padres e membros da Guarda Nacional.

\footnotetext{
${ }^{39}$ Tradução livre: Pedro em tudo ou em todas as funções.

${ }^{40}$ Monitor Campista, Campos dos Goytacazes/RJ, $\mathrm{n}^{\circ}$ 11, 25 jan. 1845. In: Arquivo Público Municipal Waldir Pinto de Carvalho, Campos dos Goytacazes.

41 Esse vigário, juiz de paz, aliado de Aureliano, nas eleições primárias, na condição de presidente da mesa paroquial, havia entrado em conflito com os demais membros por não concordar com a anulação de vinte votos respaldados por procurações que foram consideradas ilegais. Diante do ocorrido, ele confiscou a urna e a levou para a Câmara Municipal, não permitindo que os votos ali depositados fossem contados. In: Monitor Campista, Campos dos Goytacazes/RJ, n 453,18 out.1844 - Arquivo Público Municipal Waldir Pinto de Carvalho, Campos dos Goytacazes.

${ }^{42}$ Monitor Campista, Campos dos Goytacazes/RJ, no 450, 29 out.1844. In: Arquivo Público Municipal Waldir Pinto de Carvalho, Campos dos Goytacazes.
} 
Numa freguesia de 13 eleitores como a de Santo Antônio de Guarulhos, por exemplo, havia três eleitores da família Ribeiro de Castro (do futuro barão de Santa Rita); dois irmãos da família Siqueira (um deles o futuro visconde de Itabapoana); o Sr. Manuel Pinto Neto Cruz (futuro barão de Muriaé) - um dos maiores produtores de açúcar e proprietário de escravos do município; um fazendeiro da família Vianna, irmão do ex-presidente da província; um desembargador e três fazendeiros; e, por fim, dois padres proprietários de escravos. $^{43}$

Nas demais freguesias, a composição social seguia essa mesma regularidade, muito embora pudesse haver uma ou outra pequena mudança, como as presenças de negociantes, professor e inspetor de escola, assim como a de um ou outro dono de mercearia de destaque na comunidade. Como já dito, numa breve pesquisa sobre as eleições locais das freguesias ao longo dos anos trinta e quarenta, entre os mais votados para vereador e juiz de paz, encontramos a recorrência dos sobrenomes de poderosas famílias de produtores de açúcar, passando o poder pelas mãos de diferentes gerações que ocupavam cargos políticos de natureza local/provincial/nacional, a exemplo dos Ribeiro de Castro, Vianna, Pereira Batista, Barbosa, entre outras. .

No dia dez de novembro, nas eleições para deputados gerais, uma polêmica se instalou à mesa de votação: se a cédula eleitoral deveria ou não ser assinada pelo eleitor. A legislação existente ${ }^{44}$ previa que tal procedimento fosse aplicado para as eleições primárias e não era explícita sobre a assinatura de cédulas nas eleições secundárias. A comissão eleitoral, então, majoritariamente, composta por partidários do novo Gabinete e do governo provincial ${ }^{45}$, acatou a proposta do delegado de polícia, Sr. José Martins Pinheiro ${ }^{46}$ de que fosse

\footnotetext{
${ }^{43}$ Monitor Campista, Campos dos Goytacazes/RJ, no 454, 05 nov. 1844. In: Arquivo Público Municipal Waldir Pinto de Carvalho, Campos dos Goytacazes.

${ }^{44}$ Decreto de 26 de março de 1824 - manda proceder à eleição dos Deputados e Senadores da Assembleia Geral Legislativa e dos Membros dos Conselhos Gerais das Províncias; e Decreto n 157 de 4 de maio de 1842, dá Instruções sobre a maneira de se proceder às Eleiçõos Gerais e Provinciais (SOUZA, 1979, p. 187-207).

${ }^{45}$ Ata da eleição de dez deputados à Assembleia Geral Legislativa, Campos dos Goytacazes/RJ, 10 nov. 1844, in: Arquivo Geral da Cidade do Rio de Janeiro.

${ }^{46}$ Trata-se de um proprietário de terras e escravos que, vinte e três anos depois, em 1867, receberá o título de barão da Lagoa Dourada. Nos anos trinta, ele também havia ocupado o
} 
colocada em votação se a cédula deveria ser assinada ou não, ${ }^{47}$ visto que, em seu modo de ver, embora a obrigação não estivesse expressa no inciso $1^{\circ}$ do capítulo $6^{\circ}$ das instruções de 26 de março de 1824 (que nada dizia sobre assinar as cédulas para deputados), poderia ser inferida quando levadas em consideração outras orientações dessas instruções em questão, como o inciso $5^{\circ}$ do capítulo $2^{\circ}$ que previa a assinatura das cédulas no caso das eleições primárias, dos eleitores dos eleitores. Ou, então, do inciso $7^{\circ}$ do capítulo $9^{\circ}$ que tratava das Providências Gerais, isto é, que "nenhum eleitor poderá nomear para Deputado, ou Senador seus ascendentes, ou descendentes, irmãos, tios e primos irmãos, sob pena de perder o voto activo e passivo". ${ }^{48}$

Dos oitenta e oito eleitores presentes, quarenta e três votaram pelo sim e quarenta pelo não, não tendo sido encontrada informação sobre os demais. Por fim, dezoito senhores se negaram a assinar as suas cédulas alegando que tinham uma outra inteligência do que deveria ser o procedimento eleitoral. Dentre eles, encontramos os mais ricos senhores de engenho que, pragmáticos, buscavam se manter fora o espírito de partido, como nos exemplos dos patriarcas Manoel Antônio Ribeiro de Castro, Manoel Pinto Netto Cruz e José Carneiro Silva. No entanto, anos depois, em 1847, as famílias desses senhores receberão com pompas e circunstâncias o presidente da província, o chefe do Gabinete e o Imperador Pedro II, momento em que se encontravam em jogo importante questões como o financiamento da construção do canal Campos-Macaé, o debate sobre o retorno do imposto de açúcar e o fim do tráfico de escravos.

A assinatura da cédula nas eleições secundárias tinha sido uma prática local entre os anos de 1832 e 1834, mas havia sido rejeitada nas eleições de 1836 e foi assim nos pleitos seguintes. No entanto, com a proposta do

cargo de delegado e estivera submetido ao ministro da justiça que era Aureliano de Souza Coutinho. Era cunhado de Gregório Francisco de Miranda, membro de uma família tradicional da cidade e um dos homens fortes de Aureliano.

47 Ata da eleição de dez deputados à Assembleia Geral Legislativa, Campos dos Goytacazes/RJ, 10 nov. 1844, in: Arquivo Geral da Cidade do Rio de Janeiro.

48 DECRETO DE 26 DE MARÇO DE 1824, manda proceder à eleição dos Deputadas e Senadores da Assembleia Geral Legislativa e dos Membros dos Conselhos Gerais das Províncias. In: $\quad$ http://www.ibrade.org/wp-content/uploads/2018/03/Decreto-de-26-demar\%C3\%A7o-de-1824.compressed.pdf. Consultado em 19/08/2019. 
delegado, a prática retornava nas eleições de $1844 .{ }^{49}$ Como os votos eram arquivados na Câmara, era possível mapear quem apoiara quem e qual o nível de comprometimento /lealdade dos eleitores locais com as diferentes facções políticas da Província e do Império, principalmente naquele momento de chegada dos liberais ao poder. Essa expectativa/realização de retribuições era um dos importantes mecanismos que faziam a máquina política funcionar na sucessão dos diferentes grupos no poder, até porque as nomeações dos cargos, a concessão de titulações nobiliárquicas, os investimentos e "favores" para o município dependiam dos serviços prestados pelas lideranças políticas locais, como no exemplo dos votos que deveriam ser dados ao governo.

Assinar a cédula era uma prática corriqueira (prevista na lei) nas eleições primárias da escolha dos eleitores para deputados, oportunizando que os senhores tivessem o controle sobre a lealdade de sua clientela, podendo, assim, mapear em quais candidatos os seus protegidos, aliados e clientes votaram. No entanto, metade dos senhores, principalmente os que se colocavam acima do espírito de partido, estava contra que a mesma "inteligência" utilizada para os seus eleitores fosse aplicada a eles, pois, em última instância, os seus votos seriam fiscalizados, haja vista que "o chefe via-se enredado em um sistema que o tornava cliente de alguém que dependia de outros, numa série de elos que alcançava a corte imperial" (GRAHAM, 1999, p. 03). Nesse caso específico, é possível que, na disputa entre Caldas Vianna e Aureliano Coutinho, eleitores mais pragmáticos não quisessem revelar que tinham escolhido a si mesmos, ou seja, queriam deixar o campo aberto para futuras negociações. Não por menos, posteriormente, num periódico local, o delegado que havia feito a proposta da assinatura das cédulas, veio se justificar: "e tanto não foi o espírito de partido que me induziu a suscitar essa questão e, sim, a convicção em que estou, como já referi que, na ocasião da entrega, eu quis e principiei a ler a minha lista". ${ }^{50} \mathrm{Em}$ seguida, ele lista os candidatos em quem

\footnotetext{
49 Monitor Campista, Campos dos Goytacazes/RJ, no 465, 13 dez. 1844. In: Arquivo Público Municipal Waldir Pinto de Carvalho, Campos dos Goytacazes.

50 Monitor Campista, Campos dos Goytacazes/RJ, no 465, p.2, 13 dez. 1844. In: Arquivo Público Municipal Waldir Pinto de Carvalho, Campos dos Goytacazes.
} 
votou, demonstrando que, apesar de sua ligação com o Presidente da província, votara também em Caldas Vianna. Porém, para os seus críticos, ele agira de forma ardilosa para tomar "conhecimento de que maneira votavam aqueles que, independentes por sua ilustração e fortuna, eram tidos por oposicionistas". 51

A linha de raciocínio usada por Martins Pinheiro para o texto legal parecia bem objetiva. No entanto, não se tratava apenas de considerar a lógica textual, mas também o contexto discursivo, ou seja, as práticas sociais (como as disputas de poder) que sustentavam as diferentes interpretações sobre a realidade política local. Dito de outro modo, "não é tanto a pureza semiótica da palavra que nos interessa, (...), mas sua ubiquidade social. As palavras são tecidas a partir de uma multidão de fios ideológicos e servem de trama a todas as relações sociais em todos os domínios" (VOLOSHINOV; BAKHTIN, 1992, p. 41). Nesse caso, nada era tão preto no branco, no interior de uma mesma classe, os grupos fizeram leituras diferente sobre o que dizia a lei, explorando nas brechas da legislação uma interpretação que conviesse aos seus próprios interesses.

Ao Norte da Província, para a eleição de deputados gerais, o colégio do município de Campos dos Goytacazes apresentou 88 votos, Macaé 38 e São João da Barra 22, somando um total de 148 votos, sendo que 18 votos de Campos foram anulados. Dos dez candidatos a deputados gerais que, segundo a oposição local, eram apoiados pelo presidente Aureliano, oito foram eleitos: Saturnino de Sousa e Oliveira Coutinho (1172 Votos na Província -VP, sendo 118 votos no Norte da Província - VNP, 66 votos no município de Campos dos Goytacazes- VCG), Thomaz Gomes dos Santos (1151 VP, 117 VNP, 67 VCG), João Paulo dos Santos Barreto (1016 VP, 103 VNP, 56VCG), Januário da Cunha Barbosa (931 VP, 87 VNP, 46VCG), Manuel de Jesus Valdetaro (1083 VP, 107VNP, 62VCG), Joaquim Francisco Alves Branco Muniz Barreto

\footnotetext{
${ }^{51}$ Monitor Campista, Campos dos Goytacazes/RJ, no 462, 03 dez. 1844. In: Arquivo Público Municipal Waldir Pinto de Carvalho, Campos dos Goytacazes.
} 
(931VP, 104 VNP, 57VCG), Bispo D. Manuel Montes Rodrigues (985 VP, 103 VNP, 54VCG), Antônio José da Veiga (941VP, 72 VNP, 25VCG). ${ }^{52}$

Nessas eleições, entre os dez mais votados, sete pertenciam a chapa indicada pelo presidente Aureliano e, de certo modo, estavam em sintonia com o novo Gabinete (FERRAZ, 2012). Nesses termos, o colégio eleitoral local concorria para a renovação da Câmara dos deputados gerais e do fortalecimento da aliança dos liberais com os palacianos. Trata-se de uma postura bem pragmática da maioria dos membros da elite política e econômica do município. Alguns dos que se recusaram a assinar a cédula eram ricos o suficiente para se colocarem acima do espírito de partido, mas não tão ricos que não precisassem demonstrar algum sorriso de simpatia pelo governo no momento mais adequado, como aconteceria em 1847, na visita de Aureliano de Souza Coutinho e Holanda Cavalcanti. Por outro lado, os conservadores declarados, fazendeiros e negociantes que não se sentiam contemplados pelo novo grupo no poder, continuaram a se posicionar contrários a gabinete de 1844 e o presidente de província.

Por fim, ainda em novembro, no caso das eleições para deputados provinciais, passou-se o mesmo que ocorrera nas eleições gerais. Nesse caso, dos 91 eleitores que foram listados no município de Campos, 20 se negaram a assinar a cédula. ${ }^{53}$ Entre os mais votados estava Bernardino José Maciel que recebeu 69 votos dos 71 que foram aceitos pela mesa. Apesar de alguns senhores locais terem sido bem votados, como o vigário João Carlos Monteiro e o desembargador José de Saldanha da Gama, apenas três candidatos ligados a cidade foram eleitos na votação total da província: Bernardino José Maciel (571 votos), o barão de Araruama (410 votos) e o bacharel em direito Josino do Nascimento Silva (675 votos). ${ }^{54}$ No entanto, esse último, que era o único natural da cidade, havia sido também eleito para deputado geral e, apesar de

${ }^{52}$ Dados obtidos a partir do cruzamento das seguintes fontes: Diário do Rio de Janeiro, 19/11/1844, no 6772, p.04./ Ata da eleição de dez deputados à Assembleia Geral Legislativa, Campos dos Goytacazes/RJ, 10 nov. 1844, in: Arquivo Geral da Cidade do Rio de Janeiro.

${ }^{53}$ Monitor Campista, Campos dos Goytacazes/RJ, no 458, 19 nov. 1844. In: Arquivo Público Municipal Waldir Pinto de Carvalho, Campos dos Goytacazes.

${ }^{54}$ Jornal do Comércio, Rio de Janeiro/RJ, nº 318, 29 nov. 1844. In: http://bndigital.bn.gov.br/. Acesso em 20 de jul. 2019. 
não constar naquela lista de Aureliano, recebera no município 70 votos para deputado provincial e 51 para deputado geral. O protesto dos conservadores em defesa dos antigos nomes e das famílias tradicionais não tardou a se ouvir:

Aonde está o nome de um filho do país que escapasse do naufrágio, à exceção do Josino!? Que é desses mesmos com que se pretendeu embalar a credulidade campista (?!), os de um Siqueira, Joaquim Pinto, João Carlos e Saldanha!? Apenas n'ela se acha a do barão de Araruama; mas este mesmo é do município de Macaé (...) O país fica, portanto, sem uma só voz na Assembleia, que propugne pelos seus direitos e pelos os seus interesses...! Que responderão a isto os degenerados Campistas que tanto favonearam o imundo aurelianismo! Aonde está o antigo poderio do Colégio de Campos que nem um só Campista apresenta na Assembleia, que ao fato de suas localidades e dos seus interesses materiais, proponha os melhoramentos e interesses do país? ? $^{5}$

De fato, nas legislaturas anteriores, sobretudo no período do regresso e do domínio dos regressistas/conservadores, os deputados naturais da terra, pertencentes às famílias tradicionais, foram mais atuantes na defesa dos interesses dos grandes produtores de açúcar. Em função da chegada dos liberais ao poder com o Gabinete de 02/02/1844, de Almeida Torres, os conservadores, via jornal Monitor Campista, passaram a tecer duras críticas aos representantes campistas na Assembleia Provincial Legislativa, como se esse suposto áureo tempo em que ocuparam o poder tivesse contemplado a todos os cidadãos. ${ }^{56}$

Entre os anos de 1820 e 1832, os "homens bons" do local empreenderam uma campanha para desmembrar a vila de São Salvador dos Campos dos Goytacazes da província do Espírito Santo e anexá-la, em definitivo, ao Rio de Janeiro, como um modo de transformar o seu potencial eleitoral em capital político nas esferas regional e nacional (LEMOS, 2018 a). Eles obtiveram sucesso nessa empreitada. Assim, entre 1834 e 1844, em certa medida, tal ambição política dos liberais moderados parece ter seguido nessa direção. Porém, na visão deles, as eleições de 1844 vinham colocar um freio ao progresso de sua cidade que, tanto ou mais do que Niterói, queria ser a capital

\footnotetext{
55 Monitor Campista, Campos dos Goytacazes/RJ, no 466, 17 dez. 1844. In: Arquivo Público Municipal Waldir Pinto de Carvalho, Campos dos Goytacazes.

${ }^{56}$ Monitor Campista, Campos dos Goytacazes/RJ, nº 466, 17 dez. 1844. In: Arquivo Público Municipal Waldir Pinto de Carvalho, Campos dos Goytacazes.
} 
da província (LEMOS, 2018b, p.163; GOUVÊA, 2008, p.33). O que essa parcela dos conservadores parecia ignorar é que as chamadas famílias tradicionais como Siqueira, Pinto, Castro e outras eram bem maleáveis em seu espectro ideológico, pois, desde que os seus interesses materiais e políticos pudessem ser atendidos, demonstravam não se incomodar tanto assim com as diferenças entre as facções. Não foi por menos que muitos pais de família da "boa sociedade" não hesitaram em assumirem cargos no novo governo "áulicoliberal".

A visita do Imperador, do presidente da Província do Rio de Janeiro e do “organizador” do Gabinete de 02 de maio de 1846.

\section{Portaria}

Pretendendo sua majestade o Imperador visitar esta Província em direção a Cidade de Campos dos Goytacazes, o mais brevemente possível, assim o comunico à Câmara da mesma cidade, não só para que faça chegar ao conhecimento dos seus munícipes a alta honra que a S. M. I. se digna fazer-lhes, como que para com toda a brevidade dê as mais urgentes e adequadas providências que estiverem a seu alcance a fim de que o mesmo Augusto Senhor encontre em bom estado as estradas desse município por onde houver de transitar, e seja nele recebido com aquela decência e acatamento devidos à sua Soberana Pessoa. Palácio do Governo da Província do Rio de Janeiro, em 29 de setembro de 1846 - Aureliano de Souza e Oliveira Coutinho. ${ }^{57}$

No final do ano de 1846, em função da visita do jovem Imperador Pedro II, que seria realizada em março do ano seguinte, a Câmara Municipal de Campos dos Goytacazes organizou diferentes comissões para levar à frente os preparativos da recepção e estadia de Sua Majestade. No comando dessas comissões participaram os vereadores, as autoridades locais e alguns membros das famílias tradicionais com diferentes inclinações políticas. Por sua vez, entre

\footnotetext{
${ }^{57}$ Editais da Câmara Municipal de Campos dos Goytacazes/RJ, 10 out. 1846. In: Arquivo Público Municipal Waldir Pinto de Carvalho, Campos dos Goytacazes.
} 
os comandados, encontravam-se voluntários como padres, militares, comerciantes, funcionários públicos e outros, enfim, todos que se diziam amantes da monarquia. E, como era de se esperar, nas frentes de trabalho mais pesadas, estavam os escravos, de ambos os sexos e de diferentes idades.

Havia muito a ser feito: limpeza e conserto das ruas e estradas, solicitação ao clero de preparação das missas e do Te Deum, contratação dos músicos, dos cantores e da dança de caboclos, mobilização da Guarda Nacional, definição da ceia que seria oferecida na chegada, o cumprimento do programa de recepção estabelecido pelo presidente da província, a elaboração de um roteiro local que incluía lugares e pessoas de destaque, reformas das residências, organização dos bailes, jantares, da companhia de teatro e, em especial, escolher as casa que serviria de palácio para a Majestade e seus criados. Sobre este último item parecia não haver dúvida, a melhor era do fazendeiro conservador José Gomes da Fonseca Paraíba que, tendo sido avisado, colocou a sua casa à disposição, não hesitando em gastar alguns contos para reformá-la. Já nas subscrições para arcarem com as despesas da luz e do transportes, a comissão arrecadou 2:583\$000 (dois contos e quinhentos e oitenta e três mil réis), sendo que as famílias mais abastadas foram as que mais contribuíram com quantias acima de $100 \$ 000 .{ }^{58}$ Por sua vez, usando de sua receita, a Câmara Municipal gastou com a recepção a quantia de 4:032\$184, praticamente um terço a mais do que gastava ao longo de um ano com o sustento dos menores abandonados, dos presos pobres e aluguel de cemitério. ${ }^{59}$

A interferência na organização do roteiro da estadia foi motivo de disputas políticas entre as facções. A primeira derrota dos conservadores foi a casa do Comendador Paraíba ser recusada como "o palácio provisório" de Pedro II, que acabou sendo transferido para a casarão de um dos senhores de engenho mais ricos da região, Manoel Pinto Neto Cruz - considerado um homem acima do espírito de partidos, dono de um grande plantel de escravos e

\footnotetext{
${ }^{58}$ Monitor Campista, Campos dos Goytacazes/RJ, nº 63, 15 jun. 1847. In: Arquivo Nacional Ministério da Justiça e Segurança Pública.

${ }^{59}$ Monitor, Campista, Campos dos Goytacazes/RJ, no 14, 08 de fev. 1848. Arquivo Nacional Ministério da Justiça e Segurança Pública.
} 
membro de uma família tradicional. Marcada por muitas fofocas depreciativas, essa transferência foi ordenada por Aureliano e capitaneada pelo Bernardino José Maciel. Uma importante razão para tal decisão foi o fato de que, desde a Abdicação de Pedro I (1831), o Comendador Paraíba, junto com o seu amigo, o jornalista liberal moderado José Alípio, tinha entrado em embates contra os liberais exaltados locais (apelidados de rusguentos) e algumas autoridades que agora compunham esse novo governo, a exemplo do senhor José Martins Pinheiro.

O imperador trazia consigo uma comitiva de mais de cinquenta pessoas (criados, guardas e alguns políticos), entre as quais se encontravam o presidente da Província do Rio de Janeiro, Aureliano de Souza e Oliveira Coutinho e o "ministro" das finanças, Antônio Francisco de Paula de Holanda Cavalcanti de Albuquerque (CASADEI, 1985, p.19). A hospedagem/recepções dessa camarilha foi dividida entre as tradicionais famílias dos Ribeiro de Castro, Carneiro da Silva, Neto Cruz, Neto Reis, Barroso Borges, Saldanha da Gama e outras poucas que ficaram responsáveis pelo oferecimento de jantares, ceias, passeios e bailes. E essas mesmas famílias, especialmente as três primeiras, monopolizaram a estadia, acompanhando o Imperador e as demais autoridades por todos os cantos e freguesias.

Muito embora os registros deixados falem pouco sobre eles, chegando mesmo a torná-los invisíveis, os escravos estavam presentes na maioria das atividades da recepção e estadia. Na realidade, o seu trabalho que possibilitou a construção dos portais de luzes e dos palanques, limpeza das ruas e estradas, pintura da frente da casa, preparação dos jantares e ceias, carregamento dos lixos e imundícies, transporte das pessoas e mercadorias, quando não dos divertimentos. Enfim, mesmo naqueles momentos em que a sua presença física não era requisitada, o seu trabalho viabilizava a ostentação dos cidadãos/súditos da "boa sociedade" local acerca do que diziam ser a hospitalidade dos interioranos.

No trajeto de Quissamã para Campos, o escaler em que ia o Imperador foi acompanhado por uma prancha na qual uma banda de crianças escravas, 
propriedade do barão de Araruama, tocava o hino nacional e outras peças musicais . A exemplo dele, alguns senhores também deslocaram os seus escravos de outras atividades para se dedicarem à recepção, mesmo aqueles cativos que estavam alugados, como era o caso dos que trabalhavam no Canal Campos Macaé. No teatro São Salvador, eram os negros que traziam as cadeiras dos seus senhores e esperavam por longas horas no corredor ou no lado de fora. Assim, depois que o espetáculo terminava, também eram eles que levavam as cadeiras de volta para as casas. O silêncio sobre os escravos, em medida proporcional, estendeu-se também para os indigentes, pobres e miseráveis que, dia após dia, permaneciam reunidos à frente do palacete imperial, na expectativa do recebimento de alguma esmola (FREIRE, 1847, p. 57).

Os bailes oferecidos ao Imperador e às autoridades foram concorridos, porém, com convidados selecionados. Não nos restou uma lista exata sobre quem foram os convidados e quem foram os excluídos. No entanto, é possível inferir de alguns relatos que os Ribeiro de Castro, Carneiro Silva, Neto Reis organizaram os principais eventos em que alguns membros das três famílias sempre estiveram presentes, recepcionando a comitiva imperial e aquelas pessoas consideradas de máxima distinção no município. Num dos poucos bailes não organizados por eles, a exemplo daquele oferecido pela família Saldanha da Gama, num reduto dos conservadores, em casarão localizado na Praça Principal da cidade, enquanto a "boa sociedade" dançava as quadrilhas e valsas ao som dos fuzileiros navais, "imenso povo se achava apinhado na praça defronte da casa e gozava de fora o que não podia gozar de dentro" (FREIRE, 1847, p. 59).

\section{As disputas políticas/ econômicas}

A visita era uma chance de a elite política e econômica local se informar sobre o plano de Aureliano a respeito do retorno do dízimo e do incentivo à produção do açúcar, de marcar uma posição sobre o debate a respeito do fim do tráfico de escravo, de garantir os recursos para o Canal Campos-Macaé e o 
Canal do Nogueira, de buscar o melhoramento das estradas com a província de Minas Gerais para otimização do comércio, de solicitar a construção de pontes para facilitarem o escoamento do café que descia de Cantagalo para São Fidélis e, depois, para São João da Barra, enfim, de agenciar os seus próprios interesses e demonstrar a lealdade à Monarquia e, em troca, quem sabe, esperar alguma distinção (LEMOS, 2017).

Por sua vez, os membros da Câmara municipal, sobretudo os que ocupavam cargo no governo, mobilizavam-se para que a recepção fizesse justiça à confiança que lhes fora depositada. E não foi uma tarefa fácil, pois, apesar da fama de rica, a cidade apresentava muitos problemas. A um ofício de outubro de 1846, no qual o presidente da província solicitava que fossem enumeradas as necessidades do município para que se pudesse expô-las para a Assembleia Provincial, eles listaram os principais problemas enfrentados e que fugiam de sua alçada, tais como a falta de escolas de primeiras letras, a inexistência de cemitérios públicos, as péssimas condições do prédio da cadeia e da igreja matriz, a falta de pontes, as dificuldades financeiras da Santa Casa de Misericórdia, entre outras demandas que se arrastavam ao longo dos anos. ${ }^{60}$

Quando nos debruçamos sobre o orçamento da Câmara para o ano financeiro de 1846 a 1847 , descobrimos que dos 29:248\$915 do total, $40 \%$ eram gastos com obras, abertura e reparos de ruas, sendo o restante dividido com o ordenado do pessoal, ajuda aos presos e expostos, aluguel de cemitério e de espaço para a Câmara, iluminação pública e assinatura de periódicos. ${ }^{61} \mathrm{De}$ qualquer modo, na visão dos conservadores, a visita era um ótimo momento para se cobrar uma posição das autoridades, considerando-se que, muito embora o município fosse um dos mais ricos da província, havia uma assimetria entre a sua contribuição para o erário e a atenção que recebia em termos de investimentos. $^{62}$

\footnotetext{
${ }^{60}$ Monitor Campista, Campos dos Goytacazes/RJ, nº 12, 09 fev. 1847. Arquivo Nacional Ministério da Justiça e Segurança Pública.

${ }^{61}$ Monitor Campista, Campos dos Goytacazes/RJ, no 14, 08 de fev. 1848. Arquivo Nacional Ministério da Justiça e Segurança Pública.

${ }^{62}$ Monitor Campista, Campos dos Goytacazes/RJ, nº 34, 03 de abril de 1847. Arquivo Nacional

- Ministério da Justiça e Segurança Pública.
} 
Na realidade, os investimentos públicos eram feitos, muito embora nem todos os senhores fossem beneficiados. No governo de Aureliano, existiram dois bons exemplos de como isso ocorreu na região: a promulgação da Lei $n^{\circ}$ 510, de 5 de abril de 1844, que previa a incrementação da produção de açúcar com a contratação do engenheiro civil, Feliciano Prates, e as inovações tecnológicas que ele traria da Europa para serem aplicadas na lavoura ${ }^{63}$; a construção do canal Campos Macaé e o grande aporte de recursos públicos para a sua execução via contratos de arrematação. Em ambos os casos, a classe senhorial abastada foi a mais beneficiada, especialmente as poderosas famílias dos Ribeiro de Castro e Carneiro Silva, ou seja, parte daqueles senhores/senhoras que recepcionaram o presidente da província e o Imperador em sua visita. De fato, essas famílias atuavam em conjunto e, não por menos, realizavam casamentos endógenos (de sobrinhas com tios) ou, então, casavamse entre elas, garantindo a continuidade da reprodução de suas condições políticas e econômicas num grupo fechado (LEMOS, 2018 b, p 26-34).

Em seu relatório de 1847, ao falar sobre as dificuldades com a receita e as crescentes necessidades da província, Aureliano retoma uma questão considerada delicada para os fazendeiros de açúcar:

Hoje que a província acaba de pagar ao engenheiro Prates um prêmio de 40 contos de réis pelo melhoramento que introduziu em Campos no fabrico do açúcar, e que deve estender-se a todas as fábricas deste produto ; hoje que a província despende uma grossa soma com um canal que tem de facilitar muito os transportes d'este gênero dos municípios onde ele mais se fabrica, parece de justiça que os lavradores de cana concorreram para o pagamento da dívida e melhoramentos da província. com uma quota igual àquela com que concorrem os lavradores de café, isto é, $4 \%$ cobrados pela mesa de rendas no ato da exportação. ${ }^{64}$

Muito embora tenham sido propagadas, essas supostas melhorias introduzidas pelo engenheiro ficaram bem aquém da expectativa, tanto foi

\footnotetext{
63 Relatório do presidente de província do Rio de Janeiro, Aureliano de Sousa Oliveira Coutinho, Rio de Janeiro, 1846, p.84. In: Arquivo Público do Estado do Rio de Janeiro.

${ }^{64}$ Relatório do presidente de província do Rio de Janeiro, Aureliano de Sousa Oliveira Coutinho, Rio de Janeiro 1847, p.44. In: Arquivo Público do Estado do Rio de Janeiro.
} 
assim que o método não se espraiou pelo município. ${ }^{65} \mathrm{Na}$ ocasião da visita, quando o Imperador esteve em uma das fazendas da família Ribeiro de Castro, na qual o experimento havia sido feito, não havia sombra dos aparelhos importados, pois já tinham sido vendidos como sucata para outro fazendeiro (FREIRE, 1847, p. 48). Pode-se afirmar que, pesando a relação custo e benefício, tudo leva a crer que, do ponto de vista do incremento imediato da produção, foram quarenta contos gastos em vão.

De qualquer modo, durante o tempo em que o presidente da província se encontrava na região, participando da comitiva do imperador, o debate sobre o seu relatório seguia na Assembleia Provincial. A questão do retorno do dízimo era combatida pelo deputado Luís Antônio Muniz dos Santos Lobo como um sacrifício para a lavoura ${ }^{66}$ e defendida pelo deputado liberal José de Assis Alves Branco sob o argumento de que o presidente não temia a impopularidade junto aos grandes fazendeiros de açúcar. ${ }^{67} \mathrm{~A}$ maior parte dos pequenos e médios fazendeiros eram evidentemente contrários à retomada do imposto, principalmente os que se encontravam endividados com os negociantes e o governo. O fato é que em abril de 1848, no Gabinete de Almeida Torres (visconde de Macaé), Aureliano de Souza foi demitido, ficando o assunto suspenso. Contudo, décadas depois, em 1870, a questão do dízimo do açúcar voltou a ser discutida com destaque na Assembleia Legislativa provincial. ${ }^{68}$

Quanto ao Canal Campos Macaé (no trecho da cidade), era uma obra em construção cuja administração estava nas mãos da família Carneiro da Silva e que fora autorizada por Aureliano. Essa via de navegação, uma das maiores de sua época, chegou a ser considerada a solução para o escoamento da produção da região em direção ao Rio de Janeiro. Contudo, no período que estamos

\footnotetext{
${ }^{65}$ Ao longo do ano de 1846 , esse debate estará presente nas páginas do jornal conservador, Monitor Campista, Campos dos Goytacazes/RJ. In: Arquivo Público Municipal Waldir Pinto de Carvalho, Campos dos Goytacazes/RJ.

${ }^{66}$ Diário do Rio de janeiro, ${ }^{\circ}$ 6763, 10 de abril de 1847. Sessão da Assembleia Legislativa Provincial de 08 de abril de 1847. In: Biblioteca Nacional Digital, https://www.bn.gov.br/. Acesso em 10 set. 2019.

${ }^{67}$ Diário do Rio de Janeiro, 14 de abril de 1847, n. 7475. Sessão da Assembleia Provincial de 10 abril de 1847.

${ }^{68}$ Assembleia Legislativa Provincial, sessão de 25 de setembro de 1870, p. 383. In: Biblioteca Nacional Digital, https://www.bn.gov.br/. Acesso em 15 out. 2019.
} 
tratando, havia acusações de que o projeto valorizava principalmente as propriedades da família Carneiro da Silva e de que favorecia a transferência de recursos públicos para os bolsos privados, possibilitando ao barão de Araruama e de seus aliados "enorme soma de dinheiro nas algibeiras, além de trazer consigo honras e grandeza". 69

Na medida em que decorria a visita, os cidadãos/súditos de oposição fizeram diversas críticas aos apoiadores do governo de Aureliano e do gabinete liberal de Holanda Cavalcanti. O embate atingiu o seu auge numa representação (abaixo-assinado) que foi escrita e entregue a S. M. Imperial, na qual os descontentes- em sua maioria pequenos e médios negociantes, proprietários, fazendeiros, lavradores e mestres de oficina - apresentavam uma espécie de dossiê sobre os supostos desmandos e ilegalidades do coletor de rendas e homem de confiança do presidente da província, Bernardino José Maciel:

Esse coletor, conhecido e respeitado apenas como chefe de partido na calamitosa época das eleições, em que sempre tem sabido pôr em prática toda a sorte de estratagemas para que triunfe e vença a eleição a que acontece a inclinar-se, ainda que para isso leve de rojo tudo quanto há de sagrado e respeitável. (...) É ele atualmente, Senhor, chefe de legião, e coletor das rendas provinciais e gerais, quarto substituto do delegado e juiz municipal, arrematante da dívida ativa provincial dos impostos de 1836 a 1845, vereador da Câmara Municipal, eleitor e síndico dos lugares santos de Jerusalém. ${ }^{70}$

A solicitação de que ele fosse demitido não foi atendida. Pelo contrário, o coletor foi incensado pelos "homens de bem", grandes produtores de açúcar e aguardente de famílias tradicionais. Bernardino José redigiu uma representação assegurando a sua boa conduta na cobrança dos impostos e, ao contrário do outro abaixo- assinado, no qual "figuravam homens sem fortuna e sem nome" ${ }^{71}$, a sua vinha assinada por "todos os ricos proprietários que maiores impostos

\footnotetext{
${ }^{69}$ Monitor Campista, Campos dos Goytacazes/RJ, 02 dez. 1848. In: Arquivo Público Municipal Waldir Pinto de Carvalho, Campos dos Goytacazes/RJ.

${ }^{70}$ Monitor Campista, Campos dos Goytacazes/RJ, 17 nov. 1848. In: Arquivo Público Municipal Waldir Pinto de Carvalho, Campos dos Goytacazes/RJ.

${ }^{71}$ Monitor Campista, Campos dos Goytacazes/RJ, 19 abr. 1856. In: Arquivo Público Municipal Waldir Pinto de Carvalho, Campos dos Goytacazes/RJ. Obs: Devemos relativizar que fossem homens sem sobrenome e fortuna, contudo, não há como negar que o grupo político dos
} 
pagam". ${ }^{72}$ Eram homens que, sendo os mais ricos da região, alguns já condecorados, tinham em torno de si uma boa clientela, ou seja, o seu colégio eleitoral particular. Dentre eles, vinte e cinco tinham sido eleitores de segunda instância que, em 1844, colaboraram para a vitória do governo nas Assembleias provincial e geral. E essa vitória era muito importante para a estabilidade do governo, haja vista que a maioria dos Gabinetes que caiu, caiu justamente por conta da oposição do legislativo (FERRAZ, 2016, p.65).

Das honras e dos títulos, com grandeza e sem privilégios

Em 15 de abril, no dia seguinte ao seu baile de despedida e anterior ao da sua partida, o Imperador fez o tão aguardado despacho dos títulos que, como era de se esperar, muita polêmica criou. Dos agraciados com títulos de nobreza, estavam os senhores das famílias que o receberam: José Carneiro da Silva, o barão de Araruama, elevado à condição de visconde com grandeza; o anfitrião Manuel Pinto Neto Cruz recebeu o título de barão de Muriaé com grandeza; o patriarca Manuel Antônio Ribeiro de Castro o de barão de Santa Rita; João Carneiro da Silva o de barão de Ururaí; e Gregório Francisco de Miranda, um dos homens de confiança de Aureliano, o de barão de Abadia. A maioria dos vereadores (à exceção dos não alinhados com o governo) recebeu algum título, como José Martins Pinheiro e Bento Benedito que receberam comendas da ordem de Cristo, assim como o fiscal Bernardino José Maciel recebeu o de cavalheiro da mesma ordem. Diversos fazendeiros e negociantes de Campos, Macaé e São João da Barra receberam alguma graça.

A escolha dos contemplados ficava a cargo do Imperador e do ministro (OLIVEIRA, 2011, p. 02), mas, segundo os descontentes com o resultado,

conservadores estava menor nessa conjuntura ou, então, mais silencioso. Infelizmente, a lista com os nomes da oposição não encontramos em nenhum lugar.

${ }^{72}$ Monitor Campista, Campos dos Goytacazes/RJ, 19 abr.1856. In: Arquivo Público Municipal Waldir Pinto de Carvalho, Campos dos Goytacazes/RJ. Obs: A pedido de Maciel, nove anos depois foi publicada no jornal a lista dos homens que o apoiaram: Manuel Pinto Neto Cruz, José Ribeiro de Castro, Joaquim Pinto Neto dos Reis, Gregório Francisco Miranda, José de Saldanha da Gama, José Martins Pinheiro e outros cinquenta e nove nomes de importantes proprietários, a maioria dos que foram condecorados pelo Imperador Pedro II. 
ambos foram influenciados por Aureliano que conhecia com mais detalhes a realidade política do local. Numa visão geral, é possível inferir que a escolha recaiu sobre os anfitriões das grandes famílias, o grupo mais ativo de fazendeiros que fazia parte do seleto grupo de eleitores, os vereadores alinhados politicamente com o governo e o grupo de funcionários públicos fieis à Monarquia que deram demonstração de lealdade nos preparativos da recepção. Por sua vez, a oposição tinha uma interpretação crítica para a escolha desses nomes: "O cofre das graças, (..), tem se tornado um verdadeiro manancial, onde os altos funcionários, os válidos dos reis emergem mãos impuras para daí tirarem meios com que remunerarem infames serviços eleitorais". ${ }^{73}$

No caso específico desse despacho de 1847, em que pesem as diferenças entre os pesquisadores sobre o papel da nobreza e o significado das titulações de modo geral (FAORO, 2001; BUARQUE DE HOLANDA, 1972), interessanos, aqui, destacar a importância da política, das eleições de 1844 e a da expectativa nutrida pelas eleições de 1848 na escolha de alguns nomes para as graças que foram concedidas e "que a nobreza reunia um grupo restrito de pessoas que, ou bem, se destacava socialmente graças à sua participação na elite política, ou então, pela sua condição de proprietários de terras" (OLIVEIRA, 2011, p. 06) Assim, subtraindo certo exagero das críticas da oposição, não há como discordar de que o alinhamento político e a capacidade de agenciar votos deu o tom na escolha de alguns dos contemplados que eram aliados de Aureliano, a exemplos de Gregório Francisco de Miranda, Bernardino José Maciel, José Martins Pereira, Agostinho dos Santos Colares, a família Ribeiro de Castro, entre outros.

\section{Considerações finais}

A visita do imperador ao Norte da Província do Rio de Janeiro pode ser pensada como uma janela que se abre para analisarmos as alianças entre as

\footnotetext{
${ }^{73}$ Monitor Campista, Campos dos Goytacazes/RJ, 29 abr.1847, n. 47. In: In: Arquivo Público Municipal Waldir Pinto de Carvalho, Campos dos Goytacazes/RJ.
} 
elites políticas e econômicas locais com os grandes do Império. Nesse caso, as eleições de 1844 foram um momento emblemático no qual pudemos problematizar como essas alianças se materializavam em ações concretas. Portanto, o significado da visita imperial para a sociedade do Norte da província do Rio de Janeiro (Macaé, Campos dos Goytacazes, São João da Barra...) - em especial para os fazendeiros do açúcar e os vereadores, é revelador sobre como a dinâmica do processo de centralização do poder se comportava na escala local, mobilizando recursos políticos e econômicos que garantiram o apoio da maior parte da classe senhorial local aos propósitos dos diferentes Gabinetes.

Nesses termos, devemos considerar que as elites políticas locais não eram meros fantoches nas mãos de poderosos que agiam numa escala maior, ou seja, grupos políticos de projeção nacional. No caso específico do Norte da Província do Rio de Janeiro, fossem conservadores, liberais ou independentes, de algum modo, via Câmara Municipal e colégio eleitoral, os grupos se articulavam para defenderem os seus interesses que, em certa medida, concorreram para o desenvolvimento da região (criação de canais navegáveis, estradas, escolas, subsídios agrícolas, suspensão de impostos, entre outros) e o loteamento dos cargos de mando na estrutura administrativa, jurídica e militar do estado brasileiro em processo de centralização.

\section{Referências}

BAKHTIN, Mikhail. Estética da criação verbal. São Paulo: Martins Fontes, 1997.

BARMAN, Roderick J. The Forging of a Nation, 1798-1852. Stanford: Stanford University Press, 1988.

BENTIVOGLIO, Júlio. Palacianos e aulicismo no Segundo Reinado - a facção áulica de Aureliano Coutinho e os bastidores da corte de D. Pedro II. Esboços: histórias em contextos globais, Florianópolis, v. 17, n. 23, p. 187-222, jun. 2010 .

BUARQUE DE HOLANDA, Sérgio (org.) História Geral da Civilização Brasileira (4). O Brasil Monárquico: Dispersão e Unidade - II/4. São Paulo, Difel, 1972. 
CARVALHO, José Murilo de. "Federalismo e Centralização no Império Brasileiro: História e Argumento" in: Carvalho, José Murilo. Pontos e Bordados - Escritos de História e Política. Belo Horizonte, Editora da UFMG, 2005.

CARVALHO, José Murilo de. A Construção da Ordem/Teatro de Sombras. Rio de Janeiro, Civilização Brasileira, 2006.

CASADEI, Thalita de Oliveira. D. Pedro II na Planície Goitacá: as viagens do Imperador ao norte da província do Rio de Janeiro. Rio de Janeiro: [S.l.: s.n.], 1985.

DOLHNIKOFF, Miriam. O Pacto Imperial: Origens do Federalismo no Brasil. Rio de Janeiro: Globo, 2005.

FAORO, Raymundo. Os donos do poder: formação do patronato político brasileiro. São Paulo: Globo, 2001.

FARIA, Sheila Siqueira Castro. Terra e trabalho em Campos dos Goytacazes, 1850-1920. (História: dissertação de mestrado). Instituto de História, Universidade Federal Fluminense, 1985.

FERRAZ, Sérgio Eduardo. A dinâmica política do Império: instabilidade, gabinetes e Câmara dos Deputados (1840-1889). Rev. Sociol. Polit., v. 25, n. 62, p. 63-91, jun. 2017.

FERRAZ, Sérgio Eduardo. O IMPÉRIO REVISITADO- Instabilidade Ministerial, Câmara dos Deputados e Poder Moderador (1840-1889). 2012. Tese (Doutorado em Ciência Política). Filosofia, Letras e Ciências Humanas, Universidade de São Paulo, São Paulo.

FRAGOSO, João Luís. Homens de grossa aventura - acumulação e hierarquia na praça mercantil do Rio de Janeiro (1790-1830). Rio de Janeiro: Civilização Brasileira, 1998.

FREIRE, Reginaldo Muniz. Itinerário da viagem de S. M. I. à província do Rio de Janeiro - seguido de todas as felicitações, discursos e versos dirigidos ao mesmo Augusto Senhor nesta ocasião. Rio de Janeiro: Tipografia Austral, 1847.

GOUVÊA, Maria de Fátima Silva. O Império das Províncias: Rio de Janeiro - 1822-1889. Rio de Janeiro: Civilização Brasileira, 2008.

GRAHAM, Richard. Clientelismo e Política no Brasil do Século XIX. Rio de Janeiro: Editora da UFRJ, 1997. 
GRAHAM, Richard. Clientelismo na cultura política brasileira - toma lá dá cá. Braudel papers. São Paulo: Instituto Fernando Braudel de Economia Mundial, 1999.

LEMOS, Carlos Eugênio Soares de. A visita do imperador. Rio de Janeiro: Autografia, 2017.

LEMOS, Carlos Eugênio Soares de. Vivendo em tempos de tirania - a Vila de São Salvador dos Campos dos Goytacazes, tão perto do Rio de Janeiro, tão longe do Espírito Santo (1808-1832). Rio de Janeiro: Autografia, 2018b.

LEMOS, Carlos Eugênio Soares de. A vila de São Salvador: província do Rio de Janeiro ou do Espírito Santo? Revista Territórios \& Fronteiras, Cuiabá, vol.11, n.2, ago.-dez., 2018 a.

MARX, Karl. O 18 de brumário de Luís Bonaparte. São Paulo: Boitempo, 2011.

MATTOS, Imar Rohloff de. O gigante e o espelho. In: GRINBERG, Keila; SALLES, Ricardo (Orgs). O Brasil Imperial: 1831-1870. v. 2. Rio de Janeiro: Civilização Brasileira, 2009.

MATTOS, Imar Rohloff de. O tempo Saquarema. São Paulo: Hucitec, 1987.

Memórias de Viagem de S.S. Majestades Imperiais às províncias da Bahia, Pernambuco, Paraíba, Alagoas, Sergipe e Espírito- -Santo. Divididas em seis partes e um aditamento. Com os retratos de SS. Majestades e das Sereníssimas Princesas as Senhoras D. Isabel e D. Leopoldina. Tomo I. Bahia. Rio de Janeiro, Typ. e Livraria de B. X. Pinto de Souza, 1861. Disponível em: <http://www2.senado.leg.br/bdsf/item/id/242431>. Acesso em: 17 out. 2016.

NUNES LEAL, V. Coronelismo, enxada e voto. 6. ed. São Paulo: Alfa Omega, 1993.

OLIVEIRA, Marina Garcia de. O Poder da Distinção e a Distinção da Recusa: Nobilitação e Construção do Estado Imperial Brasileiro. Anais do XXVI Simpósio Nacional de História -ANPUH São Paulo: julho, 2011.

PUTNAM, R. D. 1976. The Comparative Study of Political Elites. New Jersey: Prentice Hall.

PEREIRA DE CASTRO, Paulo. “A Reação Monárquica: Política e Administração de 1840 a 1848" in Buarque de Holanda, Sérgio (org.) História Geral da Civilização Brasileira (4). O Brasil Monárquico: Dispersão e Unidade - II/4. São Paulo, Difel, 1972. 
SCHWARCZ, Lilia Moritz. As barbas do Imperador - D. Pedro II um monarca nos trópicos. São Paulo: Companhia das Letras, 1998.

SILVEIRA, Patrícia Gomes da. A Metrópole é Aqui: redes de abastecimento e o porto do Rio de Janeiro no comércio de cabotagem, 1799-1822. Rio de Janeiro, 2013. Dissertação de Mestrado em Geografia. Programa de Pós Graduação em Geografia (PPGG-UFRJ), 2013.

SOUZA, Francisco Belisário Soares de. O sistema eleitoral no Império (1872). Com apêndice contendo a legislação eleitoral no período 1821-1889. Brasília: Senado Federal, 1979.

VOLOCHINOV, V.N.; BAKHTIN, Mikhail. Marxismo e Filosofia da Linguagem. São Paulo: Editora Hucitec, 1992.

Recebido em: 4 de maio de 2020 Aceito em: 28 de junho de 2021 